\title{
EFFECT OF MIXTURE OF SODIUM CHLORIDE AND POTASSIUM LACTATE ON THE VIABILITY OF TOXOPLASMA GONDII IN MEAT
}

\author{
BASEM REFAT NAGEIB ${ }^{1}$ AND MOHAMED HAMDY MOHAMED ${ }^{2}$ \\ ${ }^{1}$ Department of Parasitology, Animal Health Research Institute, Assiut Regional Lab. \\ (AHRI), Agriculture Research Center, Egypt. \\ ${ }^{2}$ Department of Food Hygiene, Animal Health Research Institute, Assiut Regional Lab. \\ (AHRI), Agriculture Research Center, Egypt.
}

Received: 28 March 2021; Accepted: 28 April 2021

\begin{abstract}
The present study is a trial to implement an accurate and easily detectable test applied on meat juice to detect $T$. gondii. Besides realization the ability of table salt mixture to deactivate $T$. gondii. In the present study seroprevalence of $T$. gondii in sheep and cattle meat juice by LAT was $21.43 \%$ and emphasis by PCR was $17.14 \%$ which indicate very strong agreement between LAT and PCR as a reference test (Kappa $=0.862)$ with high specificity $(94.83 \%)$ of meat juice LAT in comparison with PCR and strong relationship between these two tests (Correlation coefficient $\mathrm{r}=0.871, \mathrm{p}<0.0001$ ). Sheep meat showed a high prevalence of $T$. gondii by both LAT and PCR tests $(42.86 \%, 34.29 \%)$, respectively. No infection was recorded among the examined cattle meat. There was a very high statistical significance between the prevalence of infection among sheep and cattle by both tests. Both ewes and rams showed the same prevalence of $T$. gondii $42.9 \%$ without showing statistical significance according to the sex of the meat animal. By mice bioassay for salt mixture on the viability of T. gondii, a mixture of ( $2 \%$ sodium chloride and $1.4 \%$ potassium lactate) was able to deactivate of $T$. gondii cyst in sheep meat after 8 hours from exposure, while low concentration ( $1 \%$ of both mixture components) has no effect.
\end{abstract}

Keywords: Toxoplasma gondii latex agglutination PCR Sodium chloride Potassium lactate

\section{INTRODUCTION}

Toxoplasmosis is one of the most common parasitic zoonoses throughout the world (Albuquerque et al., 2011), which caused by an obligate intracellular, protozoan parasite Toxoplasma gondii that infects virtually all warm-blooded animals,

Corresponding author: Basem Refat Nageib E-mail address: basemnageib@gmail.com

Present address: Department of Parasitology, Animal Health Research Institute, Assiut Regional Lab. (AHRI), Agriculture Research Center, Egypt. including humans, livestock, birds, and marine mammals (Sharif et al., 2007 and Dubey, 2010). According to WHO (2015) about $50 \%$ of the cases of toxoplasmosis are thought to be foodborne.

Toxoplasma gondii has a biphasic life cycle, with an asexual phase in several tissues of herbivorous or omnivores intermediate hosts and a sexual phase in domestic cats as well as several species of wild felids (Dubey, 2010). The definitive host (cat) passes oocysts in its faeces that contaminate the environment where they 
can remain viable for long periods. Intermediate hosts, such as livestock were infected by ingesting contaminated food or water leading to the formation of tissue cysts, containing $T$. gondii, which can remain viable for the lifetime of the host (Dubey, 2010).

Sheep as well as goat and pig, are more widely and most seriously affected by Toxoplasma gondii among livestock animals (Glor et al., 2013). These food animals have the most cyst incidence in meat and play a crucial role as a source of infection for humans (Halos et al., 2010). Although most infections in small ruminants are asymptomatic, toxoplasmosis considered as a major cause of abortion, foetal mummification, stillbirths and birth of weak lambs (Anastasia et al., 2013).

In cattle, natural infection with $T$. gondii does not appear to cause clinical disease or abortion (Holec-Gasior et al., 2013). Although cattle appear to be poor hosts for $T$. gondii, cattle can still infected with $T$. gondii that pose a risk for toxoplasmosis in people who consume raw or undercooked meat and unpasteurized milk (Dong et al., 2018).

About one third of the global human population has been infected with this parasite. Most infections are asymptomatic; however, there can be severe neurological and pulmonary signs in immunosuppressed people (Hamilton et al., 2014). It is estimated that approximately 400-4,000 children are born with congenital $T$. gondii infection in the United States each year (Dubey et al., 2005).

The economic losses due to toxoplasmosis in livestock are still relatively high in many countries especially in sheep and goat industries because it induces abortion, stillbirth, and neonatal losses, as well as public health concerns as consumption of contaminated meat and milk affecting human health (Tenter et al., 2000 and Dubey, 2010).

As reported in a multi-center case control study in Europe, the risk factor powerfully predicated acute $T$. gondii infection was intake of insufficiency cooked or cured meat containing viable bradyzoites cysts. As, the eating of meat products was contributed to 30 to $63 \%$ of infection at different centers and just 6 to $17 \%$ to contaminated soil with sporulated oocysts (Cook et al., 2000). Meanwhile, the U.S. Agriculture Department expect that fifty percent of $T$. gondii infections recorded in United States was caused by consumption of viable $T$. gondii tissue cysts from raw or undercooked meat (Buzby and Roberts, 1996).

Several serological tests available to detect $T$. gondii infection in animals include Enzyme Linked Immunosorbent assay (ELISA), Latex agglutination test (LAT) and immunofluorescence antibody test (IFAT) these tests are generally highly sensitive and have been largely used worldwide (Glor et al., 2013).

As $T$. gondii can't be detected during routine meat inspection, which is considered a contributing factor for the dissemination of this disease (Fajardo et al., 2013). Therefore, the use of serology of meat juice would be ideal for large-scale examination of $T$. gondii prevalence in slaughterhouse (Vismarra et al., 2016). Meemken et al., (2014) coincided that the serology of meat juice (MJS) has proved to be an excellent way to detect $T$. gondii infection at a slaughterhouse in various animals, including sheep and pigs and was shown to correlate well with serum serology. 
Recently, great research efforts were directed to the inactivation of $T$. gondii bradyzoite in fresh meat products. Some data proposed that $\mathrm{NaCl}$ (the main ingredient in dry-cured product) or $\mathrm{NaCl}$, combinations, was able to inactivate bradyzoites in fresh pork (Hill et al., 2018). Through the lately developed deactivation data and recently developed curing process, these data provide a basis for a searchable to create a perfect design of inactivation for $T$. gondii in cattle and sheep meat.

This study aims to investigate the seroprevalence of $T$. gondii among the most widely used meat-producing animals (cattle and sheep) through analysis of meat juice. Concurrently that assists enforcement of simple, reliable, easily accurate and available commercial latex agglutination test (LAT) and comparing it with molecular biology techniques (PCR). In addition to aiding the meat processor in the prevention of $T$. gondii transmission from cattle and sheep meat to humans through applying different concentration from sodium chloride and potassium lactate mixture.

\section{MATERIALS AND METHODS}

\section{Collection of Samples:}

A total of 70 meat samples were obtained from 35 sheep (14 rams, 21 ewes) and 35 cattle (26 bulls, 9 cows) were collected from Assiut city abattoir (ovine 35 and bovine 17) and Bakor village abattoir (bovine 18) during the period from September 2019 to March 2020. From each carcass about $100 \mathrm{gm}$ of diaphragmatic and skeletal muscles, were taken in labeled sterile plastic bags. Samples were immediately transported in ice tank to the Animal Health Research Institute, Assiut Lab. where kept frozen at $-14{ }^{\circ} \mathrm{C}$. The samples were analyzed as quickly as possible to maximize the viability of $T$. gondii that might be present in muscles.

\section{Meat juice preparation:}

About 2-5 ml of meat juice was obtained by freezing approximately $100 \mathrm{~g}$ of meat sample at $-14^{\circ} \mathrm{C}$ for $18-24$ hours, followed by thawing overnight at room temperature. Meat juice samples were submitted for serological analysis by LAT immediately after thawing (Bacci et al., 2015 and Mikaeel \& Omer 2015).

\section{Latex agglutination test (LAT)}

The assay was done by using (Atlas Toxo Latex Kit, Atlas Medical, UK). Briefly, according to company instructions, meat juice samples and reagents brought to room temperature. Via a micropipette, 40 $\mu \mathrm{l}$ of undiluted meat juice samples was placed onto the slide black area, $20 \mu \mathrm{l}$ of well shaked toxo latex was added to meat juice sample, mixed well by means of stirring stick, the slide was rotated slowly. Within 4 minutes the sample was checked for agglutination (Mikaeel and Omer 2015; Abdel-Aziz et al., 2020).

\section{Polymerase Chain Reaction (PCR) assay for identification of $T$. gondii specific DNA:}

The positive samples of meat juice by LAT (No.=15samples) were sent to the Reference laboratory for veterinary Quality Control of poultry production in Animal Health Research Institute, Dokki, Giza, Egypt, for identification of T. gondii specific DNA by PCR.

4.1. DNA extraction: as described by QIAGEN (2016), DNA extraction from meat samples were performed using the QIAamp DNA Mini kit (Qiagen, Germany, $\mathrm{GmbH}$ ) with modifications from the manufacturer's recommendations. Briefly, $25 \mathrm{mg}$ of the meat sample was incubated with $20 \mu \mathrm{l}$ of proteinase $\mathrm{K}$ and $180 \mu \mathrm{l}$ of ATL buffer at $56{ }^{\circ} \mathrm{C}$ overnight. Then, 200 
$\mu \mathrm{l}$ of AL buffer was added to the lysate and incubated again for $10 \mathrm{~min}$. at $72{ }^{\circ} \mathrm{C}$, after incubation $200 \mu \mathrm{l}$ of $100 \%$ ethanol was added to the lysate. The lysate was transferred to silica column, centrifugated. The samples were washed and centrifuged following the manufacturer's recommendations. Nucleic acid was eluted with $100 \mu \mathrm{l}$ of elution buffer provided in the kit.

4.2. Oligonucleotide Primer: as previously described by (Tavassoli et al., 2013), TOX4 and TOX5 primers which supplied from Metabion (Germany) that listed in table (1) were used.

4.3. PCR amplification: Primers were utilized in a $25-\mu 1$ reaction containing 12.5 $\mu 1$ of EmeraldAmp Max PCR Master Mix (Takara, Japan), $1 \mu$ of each primer of 20 pmol concentrations, $4.5 \mu$ of water, and 6 $\mu \mathrm{l}$ of DNA template. The reaction was performed in a T3 Biometra thermal cycler, amplicon sizes and cycling conditions were listed in table (1) (Tavassoli et al., 2013).

4.5. Analysis of the PCR Products: It was carried out according to Sambrook et al. (2001) in brief, the products of PCR were separated by electrophoresis on $1.5 \%$ agarose gel (Applichem, Germany, GmbH) in $1 \mathrm{x}$ TBE buffer at room temperature using gradients of $5 \mathrm{~V} / \mathrm{cm}$. For gel analysis, $15 \mu \mathrm{l}$ of the products was loaded in each gel slot. Generuler 100 bp DNA Ladder (Fermentas, Germany) was used to determine the fragment sizes. The gel was photographed by a gel documentation system (Alpha Innotech, Biometra) and the data was analyzed through computer software.

Table 1: Primers sequences, target genes, amplicon sizes and cycling conditions.

\begin{tabular}{|c|c|c|c|c|c|c|c|}
\hline \multirow[b]{2}{*}{ Target } & \multirow[b]{2}{*}{$\begin{array}{c}\text { Primers } \\
\text { sequences }\end{array}$} & \multirow[b]{2}{*}{$\begin{array}{c}\text { Amplified } \\
\text { segment (bp) }\end{array}$} & \multirow[b]{2}{*}{$\begin{array}{c}\text { Primary } \\
\text { denaturation }\end{array}$} & \multicolumn{3}{|c|}{ Amplification (35 cycles) } & \multirow[b]{2}{*}{$\begin{array}{c}\text { Final } \\
\text { extension }\end{array}$} \\
\hline & & & & $\begin{array}{c}\text { Secondary } \\
\text { denaturation }\end{array}$ & Annealing & Extension & \\
\hline \multirow{2}{*}{$\begin{array}{l}\text { T. gondii } \\
\text { B1 } \\
\text { fragment }\end{array}$} & $\begin{array}{c}\text { CGCTGCAGG } \\
\text { GAGGAAGA } \\
\text { CGAAAGTTG }\end{array}$ & \multirow{2}{*}{529} & $94^{\circ} \mathrm{C}$ & $94^{\circ} \mathrm{C}$ & $55^{\circ} \mathrm{C}$ & $72^{\circ} \mathrm{C}$ & $72^{\circ} \mathrm{C}$ \\
\hline & $\begin{array}{c}\text { CGCTGCAGA } \\
\text { CACAGTGCA } \\
\text { TCTGGATT }\end{array}$ & & $5 \mathrm{~min}$. & $30 \mathrm{sec}$. & $40 \mathrm{sec}$. & $45 \mathrm{sec}$. & 10 min. \\
\hline
\end{tabular}

5. Efficacy of sodium chloride and potassium lactate mixture on the viability of $T$. gondii

\subsection{Preparation of samples for viability of $T$. gondii bioassay \\ Samples processing}

For the bioassays, $150 \mathrm{gm}$ were collected from positive serological sheep meat specimens' stored at $4{ }^{\circ} \mathrm{C}$ for 1 day and divided into three groups (50 gm for each group). One group was set as test positive control and the other two groups were set for applying the two meat experimental treatments.

\subsection{Group treatments design for bioassays}

To settle on the most applicable salts concentration which has highly significant impact on tissue cyst infectivity in sheep meat, this experiment design into two treatment groups. The first treatment (Treatment I), is composed of sodium chloride $1 \%$ and potassium lactate $1 \%$. The second treatment (Treatment II), is 
composed of sodium chloride $2 \%$ and potassium lactate $1.4 \%$.

\subsection{Steps of test procedures}

\subsubsection{Preparation of treatment samples}

Meat of each group was immersed in corresponding treatment for 15 minutes and later on hold at $4^{\circ} \mathrm{C}$ for 8 hours before proceeding test sequences (Hill et al., 2004).

\subsubsection{Bioassays of Tissues in Mice}

As stated by (Dubey, 2010 and Jennes et al., 2017) briefly, for each group (treatment I, treatment II and control positive groups) $50 \mathrm{gm}$ of meat group was homogenized in a blender for 30 seconds in $250 \mathrm{ml}$ of $(0.85 \%) \mathrm{NaCl}$ solution prewarmed at $37^{\circ} \mathrm{C}$. After homogenization, prewarmed $\left(37^{\circ} \mathrm{C}\right) 250 \mathrm{ml}$ of pepsin solution (pepsin $1.3 \mathrm{~g}, \mathrm{NaCl} 2.5 \mathrm{~g}$, HCL $3.5 \mathrm{ml}$ and distilled water to make $250 \mathrm{ml}$ ) was added and incubated at $37{ }^{\circ} \mathrm{C}$ for $1 \mathrm{hr}$. The homogenate was filtered through two layers gauze and centrifuged at $1200 \mathrm{x} g$ for $10 \mathrm{~min}$. The sediment was resuspended in 20ml Phosphate-Buffered Saline (PBS) (pH 7.2) and $15 \mathrm{ml}$ of $1.2 \%$ sodium bicarbonate $(\mathrm{pH}$ 8.3) with additional centrifugation for 10min. The pellet resuspended in $10 \mathrm{ml}$ PBS supplemented with $40 \mathrm{IU} / \mathrm{ml}$ gentamicin. The tissue suspension from each group was inoculated intraperitoneally into five Swiss Albino female mice ( $1 \mathrm{ml} / \mathrm{mouse})$. Swiss Albino female mice seronegative for $T$. gondii were obtained from Animal Laboratory Unit of Assiut University, Assiut, Egypt.

As previously described by (HashemiFesharki 1996 and Dubey et al., 2005) mice were investigated daily for six weeks post inoculation. Mice showed ascites or emaciation 7-14 post inoculation were culled. Then the blood and peritoneal exudates were examined microscopically for tachyzoites. Mice that stayed alive for six weeks were euthanized. Impression smears prepared from (brain, lung and liver) were fixed in methyl alcohol, stained with Giemsa and were examined microscopically under oil immersion objectives $(\times 100)$ lens.

Sera from these mice were examined by Latex agglutination test (Dubey, 2010).

\section{Statistical analysis}

Statistical analysis was performed using GraphPad Prism 8.0 software (GraphPad Software Inc., San Diego, CA, USA). The data were analyzed using the chi-square test or Fisher's exact test to assess the association between prevalence and risk factors. While "P" value of $<0.05$ was considered statistically to be significant (Dong et al., 2018).

The correlation between LAT and PCR (Correlation coefficient $r$ ), specificity of LAT and the agreement among these tests, inter-rater agreement (kappa) was calculated and kappa values $(\kappa)$ were considered as follows: poor agreement $(\kappa<$ $0.20)$; fair agreement $(\kappa=0.21-0.40)$; moderate agreement $(\kappa=0.41-0.60)$; good agreement $(\kappa=0.61-0.80)$; or very good agreement $(\kappa=0.81-1.00)$ were calculated using a statistical software program (MedCalc for Windows, version 19.0.7, Med- Calc Software, Mariakerke, Belgium (Glor et al., 2013). 


\section{RESULTS}

Table 2: Prevalence of $T$. gondii among sheep and cattle by using Latex agg. Test and PCR

\begin{tabular}{cccccc}
\hline & \multirow{2}{*}{$\begin{array}{c}\text { Examined } \\
\end{array}$} & No. & \multicolumn{2}{c}{ LAT *** } & \multicolumn{2}{c}{ PCR *** } \\
\cline { 3 - 6 } & 35 & Inf. & $\%$ & Inf. & $\%$ \\
\hline Sheep & 35 & 0 & $0 \%$ & 0 & $0 \%$ \\
\hline Cattle & 70 & 15 & $21.43 \%$ & 12 & $17.4 \%$ \\
\hline Total & & & & &
\end{tabular}

*** Very high statistical significance between the sheep and cattle by LAT $\left(\chi^{2}=19.09\right.$, $\mathrm{P}<0.0001)$

**** Very high statistical significance between the sheep and cattle by PCR $\left(\chi^{2}=15.99\right.$, $\mathrm{P}<0.0001)$

Table 3: Effect of sex on the prevalence of $T$. gondii in sheep

\begin{tabular}{cccccc}
\hline & \multirow{2}{*}{$\begin{array}{c}\text { Examined } \\
\text { No. }\end{array}$} & \multicolumn{2}{c}{ LAT } & \multicolumn{2}{c}{ PCR } \\
\cline { 3 - 6 } & 14 & Inf. & $\%$ & Inf. & $\%$ \\
\hline male & 21 & 9 & $42.86 \%$ & 3 & $21.43 \%$ \\
\hline female & 35 & 15 & $42.86 \%$ & 12 & $34.86 \%$ \\
\hline Total & & & & & \\
\hline
\end{tabular}

Table 4: Mice bioassay for salt mixture on the viability of $T$. gondii (Mice inoculated, $\mathrm{n}=$ $5 /$ group)

\begin{tabular}{|c|c|c|c|c|}
\hline & \multirow{3}{*}{$\begin{array}{l}\text { Salt mixture } \\
\text { concentration }\end{array}$} & \multicolumn{3}{|c|}{ Results after 6 weeks } \\
\hline & & \multirow{2}{*}{$\begin{array}{c}\text { Sera } \\
\text { examined by } \\
\text { LAT }\end{array}$} & \multicolumn{2}{|c|}{ T. gondii cyst } \\
\hline & & & $\begin{array}{l}\text { (brain, lung } \\
\text { \& liver) }\end{array}$ & $\begin{array}{c}\text { peritoneal } \\
\text { exudates }\end{array}$ \\
\hline Control & Not add & Infective & Infective & Infective \\
\hline Treatment I & $\begin{array}{c}1 \% \text { of both sodium } \\
\text { chloride } \& \text { potassium } \\
\text { lactate }\end{array}$ & Infective & Infective & Infective \\
\hline Treatment II & $\begin{array}{l}2 \% \text { sodium chloride } \& \\
1.4 \% \text { potassium lactate }\end{array}$ & Non infective & Non infective & $\begin{array}{l}\text { Non } \\
\text { infective }\end{array}$ \\
\hline
\end{tabular}



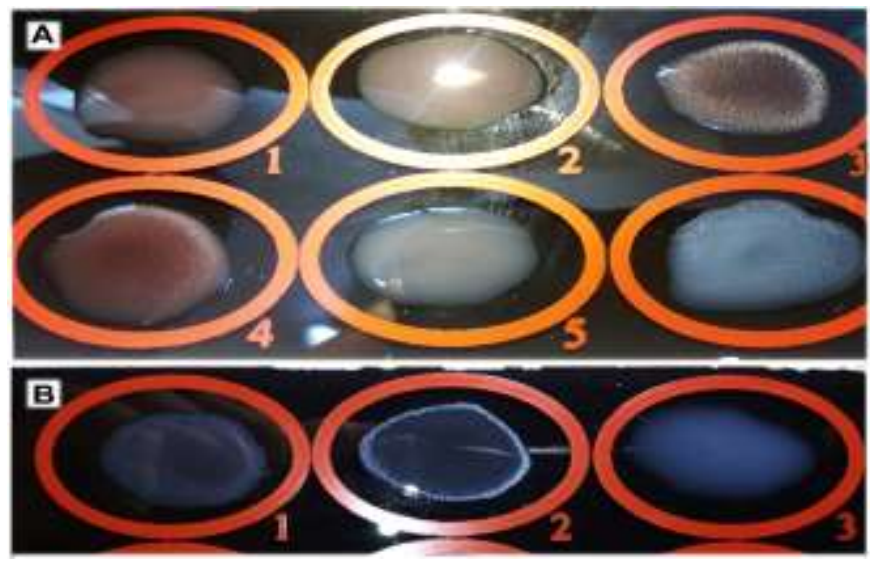

Plate (1): (A): Latex Agg. Test of meat juice showing positive agglutination reaction (circle 3, 4 and 6) while circle (1,2 and 5) were negative.

(B): Latex Agg. Test of mice bioassay sera showed positive reaction (circle 1) for (Treatment I) and circle (2) for (Control positive), while circle (3) was negative corresponding to Treatment II group.

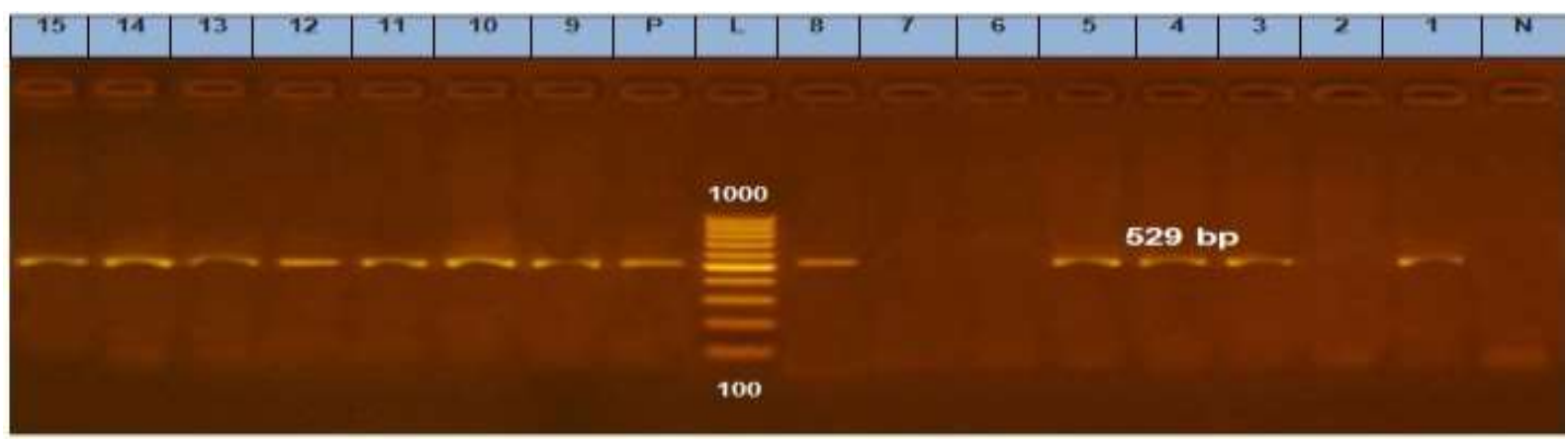

Plate (2): PCR results of Toxoplasma gondii in meat of the 15 seropositive LAT meat juice samples. Note: lane L: represents 100 bp ladder, lane N: control negative, lane P: control positive, lanes $1,3,4,5,8,9,10,11,12,13,14$ and 15: positive samples.

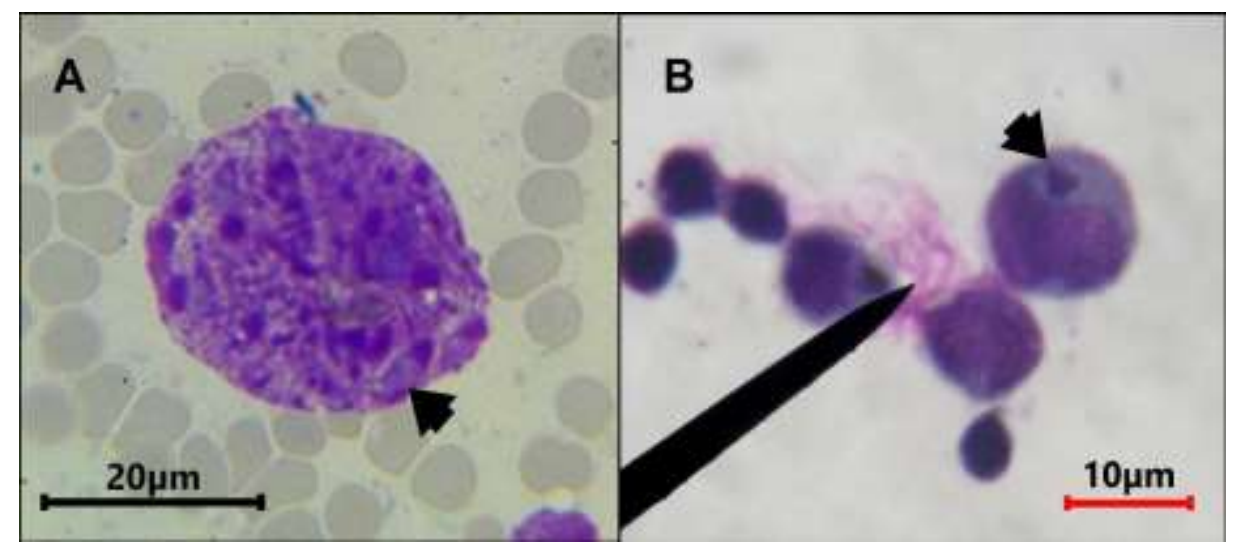

Plate (3): A: Toxoplasma gondii Cyst in impression smear from liver of experimentally infected mouse containing bradyzoite (Arrow head).

B: peritoneal exudates of experimentally infected mouse: note monocyte containing bradyzoite of Toxoplasma gondii (Arrow head). 


\section{DISCUSSION}

The overall prevalence of $T$. gondii among both sheep and cattle by meat juice LAT was $21.43 \%$ as shown in Table (2), Plate (1A). This result nearly similar to Zakaria (2011) in Hamdania slaughter house, Iraq 27\% (54/200) by LAT while lower than Mikaeel and Omer (2015) in Duhok abattoir, Iraq $43.4 \%$ (40/92) by LAT. These differences may be due to multi-factorial effects of management practice, hygienic measures, density of cats (final host), pastures contamination by $T$. gondii oocysts as well as environmental conditions including humidity, warm weather and suitable aeration in such localities (Zakaria, 2011 and Abdel-Aziz et al., 2020).

Direct detection of parasite-specific DNA can be achieved by PCR. This method has proved to be simple, rapid, sensitive, reproducible and cost-effective, which can be applied to a variety of clinical samples (Su, 2010). As mentioned by (Dubey, 2010 and Su, 2010) there are many different markers, but the 35-copy B1 gene128 and the 300copy 529-bp element are most frequently used. Validation of meat juice LAT positive samples of by PCR (Table 2, Plate 2) showed that 12 out of the examined 15 samples were positive by PCR with an overall prevalence $17.14 \%$ (12/70).

Very strong agreement (Inter-rater agreement) between LAT and PCR $($ Kappa $=0.862$, Standard error $=0.077)$ have been detected. This agreement concede with former results published by Glor et al. (2013) that found a good agreement between meat juice-ELISA and real-time PCR $(\kappa=0.659)$.
Moreover, Hamilton et al. (2015) found that a moderate level of agreement between positive meat juice ELISA and positive PCR results $(\kappa=0.5030)$.

The obtained results avowed that meat juice LAT had a high specificity (94.83\%) in comparison with PCR as a reference test and presence of strong relationship between these two tests (Correlation coefficient $r=0.871$, $\mathrm{p}<0.0001)$. This results agreed with Glor et al. (2013) who found that the specificity of meat juice commercial ELISA was $91.76 \%$ with respect to realtime PCR. Moreover, Esteban-Redondo et al. (1999) mentioned that, several former studies have compared the traditional methods of Toxoplasma diagnosis including detection of specific antibodies with the PCR and have shown a good correlation between these techniques in the diagnosis of infection.

Among food animals, sheep along with goats and pigs, possess the highest incidence of cysts in meat, which playing an important role as a source of infection for humans (Glor et al., 2013). Sheep, (Table 2) showed high prevalence of $T$. gondii $42.86 \%(15 / 35)$ by LAT, as well as by PCR $34.29 \%$ (12/35). Tenter et al. (2000) and Glor et al. (2013) mentioned that the global seroprevalences of toxoplasmosis ranging from $4 \%$ to $95 \%$ have been reported for sheep. Furthermore, high prevalence of $T$. gondii among livestock animals especially sheep were recorded in many areas of Egypt, (Ghoneim et al., 2010) found that $98.4 \%$ and $67.7 \%$ of the examined sheep were positive for $T$. gondii in El Fayoum Governorate by ELSA and PCR, respectively. Moreover, Shaapan et al. (2008) and Barakat et al. (2009) reported that the seroprevalence of $T$. gondii among sheep in Cairo and 
Giza Governorates were $41.7 \%$, 44\%, respectively via using ELISA. Similarly Kuraa \& Malek (2016) and Abdel-Aziz et al. (2020) found that the seroprevalence of $T$. gondii infection among sheep in Assiut and Sohag governorates by latex agglutination test (LAT) were $44 \%, 45.8 \%$, respectively. In Italy, Masala et al. (2003) reported that out of 2471 ovine fetal samples (11.1\%) were $T$. gondii PCR-positive. Likewise, Hamilton et al. (2015) detected $T$. gondii DNA in $16 \%$ of the tested sheep hearts in St. Kitts and Nevis, West Indies. These differences may be attributed to the geographical distribution, the environmental condition that improve the sporulation of the oocysts of T. gondii, availability of the final host or probably due to different management methods in breeding of such animals (Masala et al., 2003, Nematollahi \& Moghddam 2008 and Abdel-Aziz et al., 2020). The high prevalence of $T$. gondii infection among sheep in the current study indicated continuous exposure of infection which may owing to the heavy environmental contamination with the sporulated oocysts, the foraging behavior and diet selection "as known" sheep are grazers tending to eat short grasses and clovers close to the soil making them more likely to encounter oocysts or due to the outdoor feeding production system of sheep in contrast to cattle which reared in close areas (Masala et al., 2003, Hamilton et al., 2014, Mikaeel \& Omer 2015).

No infection was recorded among the examined 35 cattle meat by LAT (Table 2, Plate 1A). These results agreed with Esteban-Redondo et al. (1999) where they could not detect $T$. gondii from the tissues samples taken from experimentally infected cattle by bioassay in mice or by using PCR. Similarly, Dubey et al. (2005) failed to isolate $T$. gondii from any of the examined 2094 beef samples from retail meat stores in USA. Moreover, Hashemi (1996) could not found antibodies to $T$. gondii in the sera from examined 2000 cows by LAT and Indirect hemagglutination test (IHAT). Likewise, Sharif et al. (2007) in Iran, reported 0\% prevalence of $T$. gondii among slaughtered cattle in Mazandaran province by IFAT. On the contrary, Holec-Gasior et al. (2013) in Northern Poland mentioned that $3.15 \%$ of the tested cattle were founded as positive, also Abdel-Aziz et al. (2020) reported that $31.3 \%$ of the tested cattle in Sohag city abattoir by LAT were positive to $T$. gondii. Unlike sheep, cattle are considered poor hosts to $T$. gondii infection. They does not appear to give rise to clinical signs or abortion in pregnant cows, since these animals have developed a more effective immune response to $T$. gondii infection than sheep which possibly enables $T$. gondii elimination from tissues, as well as transient antibody responses (HolecGasior et al., 2013 and Dong et al., 2018). Statistically there was very high statistical significance between the prevalence of infection among sheep and cattle by both LAT and PCR $\left(\chi^{2}=19.09\right.$, $\mathrm{P}<0.0001)$ and $\left(\chi^{2}=15.99, \mathrm{P}<0.0001\right)$, respectively.

Both ewes and rams meat showed the same prevalence of $T$. gondii $42.9 \%$ (6/14) and $42.9 \%$ (9/21), respectively by using LAT Table (3). However PCR results confirmed that ewes showed higher prevalence $(9 / 21) 42.86 \%$ than rams (3/14) $21.4 \%$ but without statistical significance $\left(\chi^{2}=0.59\right)$. Higher susceptibility of ewes than rams were previously reported by Van der Puije et $a l$. (2000) in Ghana (35.8\% and 21.1\%), respectively and by Gebremedhin et al. 
(2013) in Ethiopia (34.39\% and 19.43\%), respectively. Also, Tilahun et al. (2018) noticed higher risk of $T$. gondii infection occurred among female sheep $38.3 \%$ ( $P$ $=0.019$ ) than in males $16.2 \%$. (Dubey, 2010 and Gebremedhin et al., 2013) attributed the higher prevalence of $T$. gondii in females than males due to the effect of female sex hormones in addition to the stress of lactation and pregnancy on the immune system. Moreover, Roberts et al. (1995) demonstrated that female mice exhibited greater levels of mortality and morbidity with development of more brain cysts than males, besides males showed enhanced Natural Killer (NK) cell activity compared with females and higher levels of cell-mediated immunity. Furthermore, (Gebremedhin et al., 2013) described that ewes are retained in the farm for longer periods for breeding and milk production therefore they exposed to infection for longer time than males that sold to slaughter when they are less than oneyear old.

Food safety affair is of increasing attention to regulatory agencies, producers and consumers. Inadequately cooked meat products and otherwise insufficiently prepared meat products have been involved in $T$. gondii infections in humans (Gamble and Patton, 2002). Therefore, meat health approaches developed to reduce the risk of $T$. gondii infection from non-thermally treated meat products. One of these approaches is the application of salts to meat. However, taste and flavors are not the only reason for the continued use of high levels of salts in foods, as the application of salt is an old way of preserving meat products. In addition to technical impacts, salt greatly enhances its microbial stability. Previous studies have shown the effectiveness of lactate- and $\mathrm{NaCl}$-based solutions for spoilage and pathogen inhibitors which consider the major causes of foodborne diseases (Mead et al., 1999). Enhancement of meats with lactate-based products increases the shelf life of meat products by 30 to $60 \%$ (Wilmink, 2000).

As the direction is to reduce salt concentration in meat products, in the present research, we study a low concentration of table salt (sodium chloride) in mixture with potassium lactate as a trial to render $T$. gondii tissue cyst nonviable in sheep meat with a short time after exposure. That achieved via using two mixture treatments, the treatment I comprise of low concentration $(1 \%)$ of both sodium chloride and potassium lactate. While treatment II includes sodium chloride $2 \%$ with potassium lactate $1.4 \%$.

In the present study mice bioassay was used for assessing the effect of treatments mixture on the viability of $T$. gondii as shown on Table (4) \& plate (3). It was revealed that control positive group and treatment I group developed $T$. gondii infection as Toxoplasma bradyzoite cyst detected in the liver, lung and brain of inoculated mice, while treatment II group failed to develop infection. Serological testing of inoculated mice sera plate (1B) agreed with bioassay results that only control positive group and treatment I group showed positive reaction by LAT while treatment II group were negative.

Treatment I, showed that there is no effect on $T$. gondii viability tissue cyst in sheep meat and that emphasized by Hill et al. (2004) who recorded that sodium chloride (1\%), sodium tripolyphosphate (0.25), and sodium diacetate either alone or in combination with other solutions 
had no effect on tissue cyst viability in mouse brain. In contrary, our treatment II killed the $T$. gondii tissue cyst in sheep meat within 8 hours after exposure at $4^{\circ} \mathrm{C}$ and that parallel to Hill et al. (2006) who recorded that within 8 hours after exposure to mixture of $1.4 \%$ potassium lactate with $\quad 0.25 \% \quad$ sodium tripolyphosphate and $0.10 \%$ sodium diacetate or exposure to mixture of $2.0 \%$ $\mathrm{NaCl}$ and $0.50 \%$ sodium tripolyphosphate at $4^{\circ} \mathrm{C}$ rendered the tissue cysts in the enhanced pork loins meat nonviable. Conversely, Hill et al. (2004) found that viability of $T$. gondii tissue cysts in pork loin was affected by exposure to solutions containing (2\%) sodium chloride, sodium lactate $(\geq$ $1.4 \%)$, or potassium lactate $(\geq 1.4 \%)$ held for a period of 7 days prior to feeding to cats, alone or in combination with other components and prevented transmission of $T$. gondii to cat.

One of the reasons for the orientation to use a mixture of sodium chloride in the present study and excluding the using sodium chloride alone, the previous studies concluded that with using sodium chloride alone there is a need to raise sodium chloride concentration with prolonged after exposure time to rendered tissue cysts nonviable. As Dubey (1997) clarified that bioassay in mice for the viability of $T$. gondii suspended in $\mathrm{NaCl}$ show that $T$. gondii tissue cysts from rodent brains survived for 49 days in $2.0 \% \mathrm{NaCl}$ and 21 days in $3.3 \% \mathrm{NaCl}$ solutions at $4^{\circ} \mathrm{C}$, while tissue cysts did not survive in $6.0 \% \mathrm{NaCl}$ solution at any temperature. Meanwhile Jamra et al. (1991) illustrate that table salt $(\mathrm{NaCl}) 3 \%$ concentration has an inactive action on $T$. gondii in 3 to 7 days storage at $4^{\circ} \mathrm{C}$, also Navarro et al. (1992) found that at the $2.00 \%$ and $2.5 \%$ sodium chloride in refrigerated storage, the salt treatments did not eliminate the $T$. gondii for less than 24 hours, and only after 48 hours did the salt effectively kill the parasite. Otherwise, Pott et al. (2013) recorded that at 2.5 and $3.0 \% \mathrm{NaCl}$ concentration, muscle tissue cysts infectivity was already inactivated within 1 day of exposure. While at lower concentration $(2.0 \%)$ of $\mathrm{NaCl}$ tissue cysts were found infective until day 8 at $4^{\circ} \mathrm{C}$.

\section{CONCLUSION}

In conclusion, the results and outcomes of this work have shown a high prevalence of $T$. gondii among sheep meat $42.86 \%$ by LAT, as well as by PCR $34.29 \%$ and no infection among cattle meat which considered sheep meat a potential risk to public health and that justify the necessity of monitoring $T$. gondii prevalence among sheep meat. Moreover, this work provides LAT of meat juice to implement as an appropriately accurate and easily detectable test, which could be considered as a large-scale promising tool. Based on the current finding of table salt mixture on the viability of $T$. gondii in sheep meat release the rational of the mixture of $2 \%$ sodium chloride and $1.4 \%$ potassium lactate to deactivate of $T$. gondii cyst after 8 hours from exposure.

\section{AUTHORS' CONTRIBUTIONS}

Nageib, B.R. validation, investigation, fieldwork, review of draft document, writing, methodology and data curation. Mohamed, M.H. conceptualization, visualization, project administration, fieldwork investigation, data analysis, editing of final document. 


\section{DECLARATION OF COMPETING INTEREST}

The authors have declared no conflicts of interest for this article.

\section{REFERENCE}

Abdel-Aziz, N.M.; Hassanien, A.A. and Arafa, M.I. (2020): Detection of Toxoplasma gondii in aborted women and meat of slaughtered sheep and cattle in Sohag city, Upper Egypt. Adv. Anim. Vet. Sci, 8(6), 680-686. [DOI: 10.17582/ journal.aavs/2020/8.6.680.686]

Albuquerque, G.R.; Munhoz, A.D.; Teixeira, M.; Flausino, W.; Medeiros, S. M. and Lopes, C.W.G. (2011): Risk factors associated with Toxoplasma gondii infection in dairy cattle, State of Rio de Janeiro. Pesquisa Veterinária Brasileira, 31(4), 287-290. [DOI: 10.1590/ S0100- 736X2011000400003]

Anastasia, D.; Elias, P.; Nikolaos, P.; Charilaos, $K$. and Nektarios, $G$. (2013): Toxoplasma gondii and Neospora caninum seroprevalence in dairy sheep and goats mixed stock farming. Veterinary parasitology, 198(3-4), 387-390. [DOI:10.1016/j.vetpar.2013. 09.017]

Bacci, C.; Vismarra, A.; Mangia, C.; Bonardi, S.; Bruini, I.; Genchi, M.; Kramer L. and Brindani, F. (2015): Detection of Toxoplasma gondii in free-range, organic pigs in Italy using serological and molecular methods. International journal of food microbiology, 202, 54-56. [DOI: 10.1016/j.ijfoodmicro.2015. 03.002]
Barakat, A.M.A.; Elaziz, M.A. and Fadaly, H.A. (2009): Comparative diagnosis of toxoplasmosis in Egyptian small ruminants by indirect hemagglutination assay and Elisa. Global Veterinaria, 3(1), 914.

Buzby, J.C. and Roberts, T. (1996): ERS updates US foodborne disease costs for seven pathogens. Food Review/National Food Review, 19(1482-2016-121439), 20-25.

Cook, A.J.; Gilbert, R.E.; Buffolano, W.; Zufferey, J.; Petersen, E.; Jenum, P.A.; Foulon, W.; Semprini, A.E. and Dunn, D.T. (2000): Sources of Toxoplasma infection in pregnant women: European multicentre case-control study. European Research Network on Congenital Toxoplasmosis. BMJ 2000, 321(7254):142-147. [DOI: org/ $10.1136 / \mathrm{bmj} .321 .7254 .142]$

Dong, H.; Lu, Y.Y.; Su, R.J.; Wang, Y.H.; Wang, M.Y.; Jiang, Y.B. and Yang, Y.R. (2018): Low prevalence of antibodies against Toxoplasma gondii in dairy cattle from China's central region. BMC veterinary research, 14(1), 315. [DOI: 10.1186/s12917-018-1629-3]

Dubey, J.P. (1997): Survival of Toxoplasma gondii tissue cysts in 0.85-6\% NaCl solutions at 4-20 C. The Journal of parasitology, 83(5), 946-949. [DOI: 10.2307/3284295]

Dubey, J.P. (2010): Toxoplasmosis of animals and humans, $2^{\text {nd }}$ ed. CRC Press Inc, Boca Raton, Florida, U.S.A, pp. 1-313.

Dubey, J.P.; Hill, D.E.; Jones, J.L.; Hightower, A.W.; Kirkland, E.; Roberts, J.M.; Marcet, P.L.; Lehmann, T.; Vianna, M.B.; Miska, $K$. and Sreekumar, C. (2005): Prevalence of viable Toxoplasma 
gondii in beef, chicken, and pork from retail meat stores in the United States: risk assessment to consumers. Journal of Parasitology, 91(5), 1082-1093. [DOI: 10.1645/GE-683.1]

Esteban-Redondo, I.; Maley, S.W.; Thomson, K.; Nicoll, S.; Wright, S.; Buxton, D. and Innes, E.A. (1999): Detection of $T$. gondii in tissues of sheep and cattle following oral infection. Veterinary Parasitology, 86(3), 155-171. [DOI: 10.1016/ s0304-4017(99)00138-7]

Fajardo, H.V.; D'ávila, S.; Bastos, R.R.; Cyrino, C.D.; De Lima Detoni, M.; Garcia, J.L.; das Neves, L.B.; Nicolau, J.L. and Amendoeira, M.R.R. (2013): Seroprevalence and risk factors of toxoplasmosis in cattle from extensive and semiintensive rearing systems at Zona da Mata, Minas Gerais state, Southern Brazil. Parasites \& vectors, 6:191. [DOI: 10.1186/ 1756-3305-6-191]

Gamble, H.R. and Patton, S. (2002): Toxoplasma pork safety-fact sheet, p. 1-4. National Pork Board, Des Moines, Iowa.

Gebremedhin, E.Z.; Agonafir, A.; Tessema, T.S.; Tilahun, G.; Medhin, G.; Vitale, M.; Di Marco, V.; Cox, E.; Vercruysse, J. and Dorny, $\quad P$. (2013):

Seroepidemiological study of ovine toxoplasmosis in East and West Shewa Zones of Oromia regional state, Central Ethiopia. BMC Veterinary Research, 9:117. [DOI: 10.1186/1746-6148-9-117]

Ghoneim, N.H.; Shalaby, S.I.; Hassanain, N.A.; Zeedan, G.S.; Soliman, Y.A. and Abdalhamed, A.M. (2010): Comparative study between serological and molecular methods for diagnosis of toxoplasmosis in women and small ruminants in Egypt. Foodborne Pathogens and Disease, 7(1), 17-22. [DOI: 10.1089=fpd.2008.0223]

Glor, S.B.; Edelhofer, R.; Grimm, F.; Deplazes, P. and Basso, W. (2013): Evaluation of a commercial ELISA kit for detection of antibodies against Toxoplasma gondii in serum, plasma and meat juice from experimentally and naturally infected sheep. Parasites \& vectors, 6(1), 85. [DOI: 10.1186/1756-33056-85]

Halos, L.; Thébault, A.; Aubert, D.; Thomas, M.; Perret, C.; Geers, R.; Alliot, A.; Escotte-Binet, S.; Ajzenberg, D. and Dardé, M.L. (2010): An innovative survey underlining the significant level of contamination by Toxoplasma gondii of ovine meat consumed in France. Int J Parasitol 2010, 40(2):193-200. [DOI: org/10.1016/ j.ijpara.2009.06.009]

Hamilton, C.M.; Katzer, F.; Innes, E.A.; and Kelly, P.J. (2014): Seroprevalence of Toxoplasma gondii in small ruminants from four Caribbean islands. Parasites \& vectors, 7:449. [DOI: 10.1186/ 1756- 3305-7-449]

Hamilton, C.M.; Kelly, P.J.; Bartley, P.M.; Burrells, A.; Porco, A.; Metzler, D.; Crouch K.; Ketzis, J.K.; Innes, E.A. and Katzer, F. (2015): Toxoplasma gondii in livestock in St. Kitts and Nevis, West Indies. Parasites \& vectors, 8: 166. [DOI: 10.1186/s13071-0150776-7]

Hashemi-Fesharki, $\quad R . \quad$ (1996): Seroprevalence of Toxoplasma gondii in cattle, sheep and goats in Iran. Veterinary parasitology, 61(1- 


\section{2), 1-3. [DOI: 10.1016/0304- 4017(95)00818-7]}

Hill, D.E.; Sreekumar. C.; Gamble, H.R. and Dubey, J.P. (2004): Effect of commonly used enhancement solutions on the viability of Toxoplasma gondii tissue cysts in pork loin. Journal of Food Protection; 67(10): 2230-2233. [DOI: $\quad$ org/10.4315/0362-028X67.10.2230]

Hill, D.E.; Benedetto, S.M.C.; Coss, C.; McCrary, J.L.; Fournet, V.M. and Dubey, J.P. (2006): Effects of time and temperature on the viability of Toxoplasma gondii tissue cysts in enhanced pork loin. Journal of food protection, 69(8), 1961-1965.[DOI: org/10.4315/0362-028X-69.8.1961]

Hill, D.E.; Luchansky, J.; Porto-Fett, A.; Gamble, H.R.; Fournet, V.M.; Hawkins-Cooper, D.S. and Dubey, J.P. (2018): Rapid inactivation of Toxoplasma gondii bradyzoites during formulation of dry cured ready-to-eat pork sausage. Food and Waterborne Parasitology, 12, e00029. [DOI: org/10.1016/ j.fawpar.2018.e00029]

Holec-Gasior, L.; Drapala, D.; Dominiak-Górski, B. and Kur, J. (2013): Epidemiological study of Toxoplasma gondii infection among cattle in Northern Poland. Annals of Agricultural and Environmental Medicine, 20(4), 653-656.

Jamra, L.M.F.; Martins, M.C. and Vieira, M.D.P.L. (1991): Action of table salt on Toxoplasma gondii. Revista do Instituto de Medicina Tropical de São Paulo, 33(5), 359363.[DOI: $10.1590 / \mathrm{S} 0036-$ 46651991000500004]

Jennes, M.; De Craeye, S.; Devriendt, B.; Dierick, K.; Dorny, P. and Cox, E. (2017): Strain-and dose dependent reduction of Toxoplasma gondii burden in pigs is associated with interferon-gamma production by CD8+ lymphocytes in a heterologous challenge model. Frontiers in cellular and infection microbiology; 7: 232. [DOI: 10.3389/fcimb.2017.00232]

Kuraa, H.M. and Malek, S.S. (2016): Seroprevalence of Toxoplasma gondii in ruminants by using latex agglutination test (LAT) and enzyme-linked immunosorbent assay (ELISA) in Assiut governorate. Tropical Biomedicine, 33(4), 711-725.

Masala, G.; Porcu, R.; Madau, L.; Tanda, A.; Ibba, B.; Satta, G. and Tola, S. (2003): Survey of ovine and caprine toxoplasmosis by IFAT and PCR assays in Sardinia, Italy. Veterinary parasitology, 117(1- 2), 15-21. [DOI: 10.1016/j.vetpar. 2003.07.012]

Mead, P.S.; Slutsker, L.; Dietz, V.; McCaig, L.F.; Bresee, J.S.; Shapiro, C. and Tauxe, R.V. (1999): Food-related illness and death in the United States. Emerging infectious diseases, 5(5), 607.[ DOI:10.3201/eid0505.990502]

Meemken, D.; Tangemann, A.H.; Meermeier, D.; Gundlach, S.; Mischok, D.; Greiner, M.; Klein, G. and Blaha, T. (2014): Establishment of serological herd profiles for zoonoses and production diseases in pigs by "meat juice multiserology". Prev Vet Med 113:589-98. [DOI: org/10.1016/j.prevetmed.2013.12.0 06]

Mikaeel, F.B. and Omer, L.T. (2015): Occurrence of anti-Toxoplasma gondii antibodies in bovine and ovine meat juice slaughtered in 
Duhok abattoir, Kurdistan regionIraq. Journal of University of Duhok, (Agri. and Vet. Sciences) 18 (1), 157-161.

Navarro, I.T.; Vidotto, O.; Giraldi, N. and Mitsuka, R. (1992): Resistance of Toxoplasma gondii to sodium chloride and condiments in pork sausage. Boletin de la Oficina Sanitaria Panamericana. Pan American Sanitary Bureau, 112(2), 138-143.

Nematollahi, A. and Moghddam, G. (2008): Survey on seroprevalence of anti-Toxoplasma gondii antibodies in cattle in Tabriz (Iran) by IFAT. American Journal of Animal and Veterinary Sciences, 3 (1): 40-42. [DOI: 10.3844/ajavsp. 2008.40.42]

Pott, S.; Koethe, M.; Bangoura, B.; Zöller, B.; Daugschies, A.; Straubinger, R.K. and Ludewig, $M$. (2013): Effects of $\mathrm{pH}$, sodium chloride, and curing salt on the infectivity of Toxoplasma gondii tissue cysts. Journal of food protection, 76(6), 10561061.[DOI:10.4315/0362-028X. JFP-12-519]

Qiagen (2016): QIAamp DNA Mini and Blood Mini Handbook 05/2016. Available at https://www.qiagen. com/us/resources/resourcedetail?id $=62 \mathrm{a} 200 \mathrm{~d} 6-\mathrm{faf} 4-469 \mathrm{~b}-\mathrm{b} 50 \mathrm{f}-$ 2b59cf738962\&lang=en.

Roberts, C.W.; Cruickshank, S.M. and Alexander, J. (1995): Sexdetermined resistance to Toxoplasma gondii is associated with temporal differences in cytokine production. Infection and immunity, 63(7), 2549-2555. [DOI: 10.1128/IAI.63.7.2549-2555.1995]

Sambrook, J.; Russell, D. and Gola, J. (2001): Molecular Cloning, $3^{\text {rd }}$. edition, A Laboratory Manual, Volume 1. Cold Spring Harbor, NY: Cold Spring Harbor Laboratory.

Shaapan, R.M.; El-Nawawi, F.A. and Tawfik, M.A.A. (2008): Sensitivity and specificity of various serological tests for the detection of Toxoplasma gondii infection in naturally infected sheep. Veterinary Parasitology, 153(3-4), 359-362. [DOI: $\quad 10.1016 / j . v e t p a r .2008$. 02.016]

Sharif, M.; Gholami, S.H.; Ziaei, H.; Daryani, A.; Laktarashi, B.; Ziapour, S.P.; Rafiei, A. and Vahedi, M. (2007): Seroprevalence of Toxoplasma gondii in cattle, sheep and goats slaughtered for food in Mazandaran province, Iran, during 2005. The Veterinary Journal, 174(2), 422-424. [DOI: 10.1016/j.tvj1.2006.07.004]

Su, C. (2010): Toxoplasma gondii. In: Liu D, editor. Molecular detection of foodborne pathogens. Boca Raton, FL: CRC Press; pp. 741751.

Tavassoli, M.; Esmaeilnejad, B.; Malekifard, F.; Soleimanzadeh, A. and Dilmaghani, M. (2013): Detection of Toxoplasma gondii DNA in Sheep and Goat Milk in Northwest of Iran by PCR RFLP. Jundishapur J. Microbiol, 6(10), e8201. [DOI: 10.5812/jjm.8201]

Tenter, A.M.; Heckeroth, A.R. and Weiss, L.M. (2000): Toxoplasma gondii: from animals to humans. International journal for parasitology, 30(12-13), 12171258. [DOI: 10.1016/s00207519(00)00124-7]

Tilahun, B.; Tolossa, Y.H.; Tilahun, G.; Ashenafi, $H$. and Shimelis, $S$. (2018): Seroprevalence and risk 
factors of Toxoplasma gondii infection among domestic ruminants in East Hararghe zone of Oromia Region, Ethiopia. Veterinary medicine international, 2018:4263470. [DOI: 10.1155/ 2018/4263470]

Van der Puije, W.N.A.; Bosompem, K.M.; Canacoo, E.A.; Wastling, J.M. and Akanmori, B.D. (2000): The prevalence of anti-Toxoplasma gondii antibodies in Ghanaian sheep and goats. Acta tropica, 76(1), 21-26. [DOI: 10.1016/s0001706x(00)00084-x]

Vismarra, A.; Mangia, C.; Barilli, E.; Brindani, F.; Bacci, $\quad$ C. and
Kramer, L. (2016): Meat juice serology for Toxoplasma gondii infection in chickens. Italian journal of food safety, 5(1).[DOI:10.4081/ijfs.2016.5586]

WHO (2015): WHO Estimates of the Global Burden of Foodborne Diseases. 2015.

Wilmink, M. (2000): Solving a meat problem. Int. Food Ingred, 6, 5253.

Zakaria, E.G. (2011): Detection of Toxoplasma gondii antibodies in different meat juices. Rafidain journal of science, 22(4), 17-25. 


\section{تأثير خليط من كلوريد الصوديم ولاكتات البوتاسيوم على حيويه المقوسة القتدية فى اللحوم باسم رفعت نجيب ، محمد حدي محد}

E-mail: basemnageib@gmail.com Assiut University web-site: www.aun.edu.eg

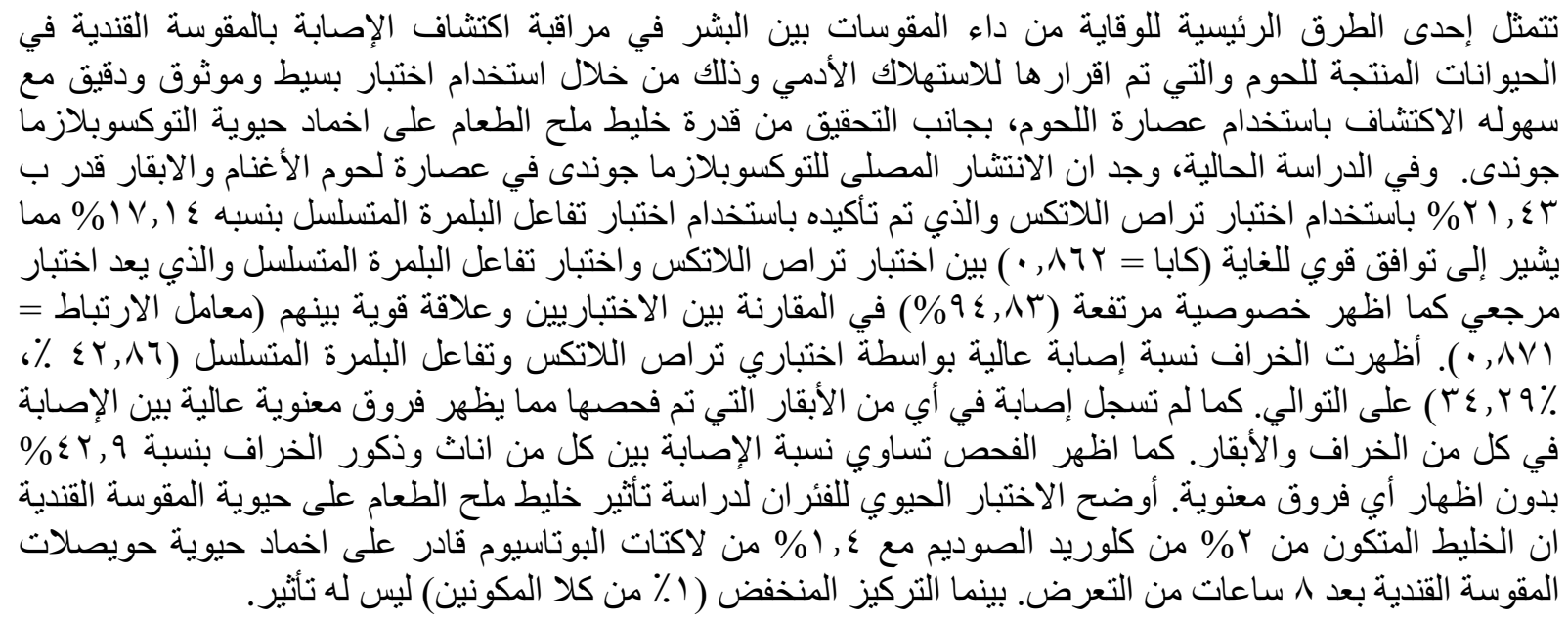

